\title{
Investigating the Effects of Different Levels of Formal Education on Iran's Economic Growth
}

\author{
Abdollah Ansari ${ }^{1}$ \\ 1 Faculty Member of Organization for Educational Research and Planning, Department of Economics of \\ Education, Institute for Educational Research, Tehran, Iran \\ Correspondence: Abdollah Ansari, Faculty Member of Organization for Educational Research and Planning, \\ Department of Economics of Education, Institute for Educational Research, Tehran, Iran. E-mail: \\ abd_ansari@yahoo.com
}

Received: October 19, 2015

Accepted: December 24, 2015

Online Published: July 16, 2016

doi:10.5539/mas.v10n9p205

URL: http://dx.doi.org/10.5539/mas.v10n9p205

\begin{abstract}
Human capital accumulation affects economic growth and education is one of the main elements of human capital. Different levels of formal education can leave different effects on economic growth. I used data from the time period of 1981-2013 and vector auto regression method to study the effects of different levels of formal education on Iran's economic growth. The results showed that increasing schooling at elementary, secondary and higher education levels have a significant effect on growth and in the long run, employees with university degrees, those with secondary and primary school qualifications had the greatest impact on GDP growth, respectively.
\end{abstract}

Keywords: human capital, formal education levels, economic growth, vector auto regression

\section{Introduction}

For many countries achieving a continuing high economic growth, which is measured by the GDP growth rate is and had been their quantitative objective. in this regard, economists have been-and still are- trying to identify those factors which can affect economic growth.

Inadequacy of factors such as changes in the workforce and physical capital stock to explain the reasons for differences in economic growth rates in different countries led the scholars to consider human capital, as one of the contributing factors. Proponents of the theory of human capital believed that education can improve the quality of human factor and labor productivity and consequently it can increase economic growth. Tendency towards the theory of human capital and education led to extensive studies in the 70's and promising results were achieved on growing effects of educational investment. The 1980s witnessed extensive attention of scientific and academic circles to the issue of economic growth and it resulted in the development of theoretical foundations of economic growth and the importance of educational investment attracted special attentions. Important inference in this regard is based on the fact that education, in addition to increasing the productivity of trainees; it can promote the productivity of those individuals who have not received any education, through positive externalities. Following the theoretical advances and providing endogenous growth patterns and according to the findings of some empirical studies previous optimistic results were confirmed, but for many developing or undeveloped countries such evidences have not been achieved (Naderi, 2004: 100 -99) and this has led to proposal of questions such as "how education increases productivity? And what level of education is suitable and the best for economic growth? Excessive investment in education is possible. In the conditions in which predicted "personal interests" due to higher education are more in comparison with low educational levels and where the direct and indirect costs of private education are relatively low, demand for education will grow dramatically. Judgment about the effectiveness of different educational levels requires different empirical studies and so in this article $\mathrm{i}$ have tried to answer to the following questions.

1. Whether various educational levels affect Iran's economic growth or not?

2. Which of the educational levels affect economic growth more?

\section{Theoretical Framework}

It is common that sources of economic growth are divided into three types of physical capital accumulation, 
labor (human resources) and technological changes. Based on a theoretical model, saving and investment accelerate economic growth and depreciation rate, population growth and growth of more technical changes will restrict the economic growth caused by loss of physical capital per capita. This article studies the effects of various factors on economic growth, identifies mentioned factors and considers them in the production function, in the form of variables. Solow (1957) developed neoclassical growth model by considering the combination of labor and capital factors and it is being shown as follows by considering the Cobb - Douglas production function:

$$
Y_{t}=A_{t} K_{t}^{a} L_{t}^{b} M_{t}^{c}
$$

In this function $Y_{t}$ is the gross production or sale, $\mathrm{L}$ is labor employment, $\mathrm{K}$ is physical capital stock and $\mathrm{A}$ represents total factor productivity that is a function of exogenous variables, such as human capital and government expenditures. So with a certain amount of inputs, the larger is the $A_{t}$, the more the production would be; however all the production changes are not explainable by changes in the physical capital stock. Moreover capital is not only limited to physical capital; but there are other aspects such as the development of quality of human resources or human investment as well which play important roles in building the capacity and developing the products and they have been used in various models. In order to consider the quality of human resources, the concept of capital has been extended to investment in human resources. For inclusion of human capital, the model can be completed by considering the different types of capital and labor force. By assuming the homogeneity of variables and considering their quality by vectors $\mathrm{H}$, the following model is obtained:

$$
Y_{t}=A_{t} K_{t}^{a} L_{t}^{b} M_{t}^{c} H_{t}^{d}
$$

In this function, $\mathrm{H}$ represents changes in the quality of inputs and it can express weighted average of education or skills. The main idea behind this approach is to fit the production measure (gross production) on production inputs. Thus, we have the following function:

$$
Y_{t}=A_{t} K_{t}^{a} L_{t}^{b} M_{t}^{c} R_{t}^{d} \cdots R_{t-n}^{e}
$$

In this function, variables $R$ represent current and past investments in knowledge (Shahbazi and Hasani, 2012: 3). Raymo (1995) has defined the production function as follows, in which capital accumulation has two forms of physical and human capital:

$$
Y=f(K, L, H K)
$$

Human capital may impact the economic growth in two different ways. First, investment in human resources assuming that other conditions are constant can increase the productivity of individuals which is based on human capital theory and the more the accumulation is, the faster the production may grow. Another way to increase the production is through transfer of new technology and its application. However, development of education may increase economic growth through providing extensive employment and opportunities to earn income for teachers, school staff, textbook print shops, workshops producing uniforms for students, boosting the housing market through schools, spill-over impacts of education on economic institutions which are near schools, formation of educated leaders class, for employment in the public service and private economic institutions, providing a kind of education to increase the level of literacy and basic skills and yet promoting a new way of thinking among different classes.

It should be noted that there is no clear procedure to explain the human capital accumulation in the production function and various ways have been used in this regard. There are various models in which the different forms of Cobb - Douglas function has been used. In these models some scholars have used the number of enrollments in high school and university levels as the human capital variable and others have used the average years of education of labor force, the proportion of university-educated work force to total labor force and some have used educational expenditures, in this context (Naderi, 2014b, p106).

\section{Research Background}

Barro (2002) showed that the number of years of education at secondary and higher levels has a significant effect on economic growth. Petrakis \& Stamatakis(2002) showed that in developing countries, primary and secondary education have significant effects on economic growth and in developed countries, higher education has a significant effect on economic growth. Lin (2004), by using data within 1968-2000 studied the effect of different levels and fields of study on economic growth of Taiwan and through applying human capital in the production function, he showed that there is no cointegration between higher education and economic growth. Papageorgiou (2003) concluded that primary education is associated with final goods production and beyond primary education is associated with application of new technology and innovation. Self and Grabofski (2004) used Granger causality method to study the effect of education on economic growth in India and found that the effect 
of primary education on economic growth is very high, but secondary education has a negligible effect on economic growth. Philippe (2006) studied the relationship between human capital accumulation and abundance of natural resources in 102 countries and showed that natural resources has a positive effect on human capital accumulation, but human capital has no effect on natural resources. Sterlacchini(2008) investigated the impact of research and development and higher education costs on economic growth of European countries, during 1995-2002 and concluded that part of the adult population with university education has a significant impact on GDP growth rates of European countries. Pereira \& Aubyn (2009) by using data from 1961 -2001 and through using vector auto regression method studied the effect of various levels of education on economic growth of Portugal and showed that increasing the level of education in all grades except the third grade has a significant and positive effect on economic growth. McMahon (2009) studied educational expenditures of various educational levels in countries with rapid economic growth in East Asia and showed that after elementary level expenditures, secondary and higher education expenditures have more significant effect on economic growth. Islam (2010) studied the relationship between human capital and productivity growth for 87 countries and concluded that highly educated labor force in middle and high income countries will lead to economic growth, but secondary education has a great role in economic growth of low income countries. Kreishan (2011) by using vector error correction model investigated the effect on economic growth of Jordan and concluded that higher education has had a positive and strong effect on economic growth. Simoes(2011)investigated the relationship between different educational levels and economic growth in OECD countries and concluded that there is a significant long-term relationship between economic growth and lower levels of education and higher education. Akguc (2011) has shown that in developed countries higher education and in least developed countries with low quality of education, primary and secondary education affect the economic growth more significantly. Ansari (1992) used data from census of 1956 to 1986 and also used Solow growth model and finally he concluded that in services and industry sectors, employees with secondary education and those with higher levels of education have been effective on value added growth, but in the agriculture sector, employees with primary education have also contributed to the growth of value added. Salehi (2002) estimated the share of university graduates in economic growth of various sectors of industry, agriculture and services and found that all the coefficients are positive which reflects the positive impact of higher education on all the economic sectors. ZarraNezhad and Ansari (2009) investigated the existence of Granger causality relation between economic growth and higher education cost and demonstrated that the mentioned variables are not the cause of each other in Iran. Abdoli and Varahrami(2009) investigated the effect of higher education on economic growth in Iran and showed that all the educational groups have a positive effect on economic growth. Almasi et al (2009) examined the effect of employing higher education graduates on economic growth, by using Johansen co-integration test and showed that in the long run human capital affects the economic growth more in comparison with physical capital. Heidari et al(2011) studied the effect of higher education employees on Iran's economic growth and concluded that, in the long run there is an equilibrium relationship between higher education and economic growth. Shahbazi et al (2012) used data from 1996-2007 and Vector Auto Regressive approach and he showed that in the long run higher education, junior secondary education and elementary education had the greatest effect on the growth of GDP, respectively. Naderi, by using data from 1959-2010 studied the effect of general and higher education and showed that different educational levels have different impacts on economic growth and general education has a greater impact on economic growth in comparison with higher education (Naderi: .2014 a, 200). Naderi (2014b) in his study entitled "Education and Economic Growth in Iran" which was conducted by using a VAR model showed that the effect of educational investment on economic growth is approximately twice the effect of physical investment. Most of conducted studies in Iran have studied the relationship between education and economic growth without considering different educational levels. Also, they have used various models, variables, data, and analyzes which makes it difficult to compare their findings.

\section{Data}

All the data (GDP and physical capital) for this research have been collected from the Central Bank of Iran and the Statistical Center of Iran and it covers the period from 1981 to 2013. Since the information related to education of employees is collected only from available data during the census years, therefore, I have utilized generalization method to generalize variable's growth process, from the past to the future in order to obtain the variable time series and it is assumed that the variable has gone through a linear path in the gap between the two censuses. Also, the capital stock time series has been estimated by considering the amount of capital stock in 1958 and the investment growth rate. 


\section{Methodology}

This study has investigated the relationship between various educational levels and Iran's economic growth, by using vector auto regression method and error correction model. The statistical research population is Iran.

Different structures and functions can be applied in order to study the effects of physical and human capital on production variations, among which the most commonly used function is Cobb-Douglas production function in which the amount of production has been explained as a function of physical capital accumulation $(\mathrm{K})$ and human capital (H C):

$$
Y_{t}=K_{t}^{a} H C_{t}^{b}
$$

In this study, the ratios of employees which have undergone formal education levels have been used as a proxy variablefor human capital variables. By taking the logarithm from both sides of the equation, we will have the following equations:

$$
\ln Y_{t}=\ln A_{t}+a \ln K_{t}+b \ln H C_{t}^{b}
$$

Used regression model (Vector Auto Regression) is shown with L lags and $\mathrm{N}$ endogenous variables as follows:

$$
X_{t}=\Pi_{1} X_{t-2}+\Pi_{2} X_{t-2}+\cdots+\Pi_{L} X_{t-L}+U_{t}
$$

In this model, vector $\mathrm{X}$ includes endogenous variables and its lags. In Vector Auto Regression models, vector $\mathrm{X}$ includes the logarithm of GDP, Logarithm of net capital stock atconstant prices of 2004 and the logarithm of percentage of employees, based on their educational status. Solow's basic model can be extended as follows:

$$
Y=K^{a} H C e_{t}^{b_{1}} H C s_{t}^{b_{2}} H C h_{t}^{b_{3}}(A)^{1-a-b_{1}-b_{2}-b_{3}}
$$

$\mathrm{HCh}, \mathrm{HCs}$ and $\mathrm{HCe}$ respectively include the proportion of employees with higher education, secondary and elementary education and all the models have been separately estimated in order to prevent the restriction resulting from a reduction in the degree of freedom. In this study, the long-run equilibrium relationship between the variables has been investigated by using Johansen - Juseliusmethod.Eviews5 and Microfit4.1 software have been used to estimate the model and to conduct the tests.

\section{Empirical Results}

\subsection{Stationary Test of Variables}

In order to estimate VAR models, we must test the stationary of variables and determine optimal number of lags. If the variables are not stationary, then the estimators will be incompatible and statistics $t$ and $F$ will not be valid for statistical inference andthe regression results can be spurious which indicates that the relationship between the variables is due to the time and it is not a real relationship between variables. When the variables are stationary, it will be optimal to use simple VAR model. When the variables are co-integrated, the regression will not be spurious. Co-integration means that although time series are non-stationary themselves, but their linear combination can bestationaryand there is a long run equilibrium relationship between them.

The next step in Vector Auto Regression models is to determine the optimal number of lags, with regard to the sample sizeand the number of variables. Determining the optimal number of Lags is necessary, because by increasing the number of lags the number of estimated variables in the model will increase proportional to the square of the number of variables and the degree of freedom of system will reduce (Shahbazi et al., 2012: 11).Augmented Dickey Fuller (ADF) test results for the variables considered in this research are presented in table 1 .

Table1. Dickey-Fuller unit root test

\begin{tabular}{llrrrr}
\hline Variable & \multicolumn{4}{c}{$\mathrm{T}=$ TrendC $=$ constant } \\
& \multicolumn{5}{c}{ Lags } \\
included & \multicolumn{3}{c}{ critical level } \\
& \multicolumn{5}{c}{ Series in levels } \\
\hline $\log (\mathrm{GDP})$ & $\mathrm{T}$ & $\mathrm{C}$ & 1 & $-1 / 73$ & $-3 / 53$ \\
$\log (\mathrm{K})$ & $\mathrm{T}$ & $\mathrm{C}$ & 1 & $-7 / 56$ & $-3 / 53$ \\
$\log (H C h)$ & $\mathrm{T}$ & $\mathrm{C}$ & 0 & $-3 / 89$ & $-3 / 53$ \\
\hline
\end{tabular}




\begin{tabular}{llllll}
\hline $\log (H C s)$ & - & $\mathrm{C}$ & 0 & $-3 / 98$ & $-2 / 94$ \\
$\log (H C e)$ & - & $\mathrm{C}$ & 1 & $-1 / 19$ & $-2 / 94$ \\
& \multicolumn{5}{c}{ Series in first differences } \\
\hline $\mathrm{D}(\log (\mathrm{GDP})) \mathrm{T}$ & $\mathrm{C}$ & 0 & $-5 / 68$ & $-3 / 53$ \\
$\log (\mathrm{K})$ & $\mathrm{T}$ & $\mathrm{C}$ & 0 & $-13 / 76$ & $-3 / 53$ \\
$\log (H C h)$ & $\mathrm{T}$ & $\mathrm{C}$ & 0 & $-9 / 69$ & $-3 / 53$ \\
$\log (H C s)$ & - & $\mathrm{C}$ & 0 & $-7 / 58$ & $-2 / 94$ \\
$\mathrm{D}(\log (H C e)-$ & $\mathrm{C}$ & 0 & $-4 / 44$ & $-2 / 94$
\end{tabular}

Source: Research findings

The upper part of the table, includes results for the series in levels and the lower part contains results for first differenced series. The results showed that the variables of logarithm of GDP and elementary education will be stationary after one time differencing and the variables of logarithm of physical capital accumulation and secondary and higher level education are stationary, as well.

Table 2. Phillips-Perron unit root test

\begin{tabular}{lcccc}
\hline Variable & \multicolumn{4}{c}{$\mathrm{T}=$ TrendC=constantADF statisticcritical level } \\
& \multicolumn{5}{c}{$\% 5$} \\
\hline $\log (\mathrm{GDP})$ & $\mathrm{T}$ & $\mathrm{C}$ & $\mathbf{- 5 . 8 7}$ & $-3 / 53$ \\
$\log (\mathrm{K})$ & $\mathrm{T}$ & $\mathrm{C}$ & $\mathbf{- 1 . 4 5}$ & $-3 / 53$ \\
& $\mathrm{~T}$ & $\mathrm{C}$ & $\mathbf{- 4 . 0 7}$ & $-3 / 53$ \\
$\log (H C h)^{\mathrm{T}}$ & & $\mathbf{- 5 . 4 8}$ & $-2 / 94$ \\
$\log (H C s)-$ & $\mathrm{C}$ & $\mathbf{- 3 . 3 4}$ & $-2 / 94$ \\
$\log \left(H C{ }^{-}\right)^{-}$ & $\mathrm{C}$ & \\
\hline \multicolumn{5}{c}{ Series in first differences } \\
\hline $\mathrm{D}(\log (\mathrm{K}))$ & $\mathrm{T}$ & $\mathrm{C}$ & $\mathbf{- 7 . 3 8}$ \\
\hline \multicolumn{5}{c}{$-3 / 53$} \\
\hline
\end{tabular}

Source: research findings

Due to the relatively long period of study, since time series can encounter structural changes, i have used Phillips-Perron unit root test. The results showed that all the variables except the capital stock are stationary and the capital stock variable will be stationary with taking one difference.

\subsection{Cointegration and Var Estimation Results}

In order to study long-term relationship between variables, the equations related to each of the VAR models were estimated by using Vector Auto Regression method and optimal lag was determined according to the minimum observed value of the Akaike Information Criterion(AIC) statistic. Even if the validity of the modelis approved due to the results of the stationary test,the co-integration test must be conducted to ensure the number of authentic relationships among variables (Naderi, 2014b: 114).So, in order to conduct Johansen-Juseliustest, we must initially determine the number of co-integration vectors, through using trace and maximum eigenvalues statistics. Co-integration test between variables (Logarithm of GDP, net capital stock and all the capital variables) was conducted by using vector error correction model and based on the Johansen - Juselius process. 
Then it was necessary to select an appropriate model to investigate the test results of Co-integration test and to consider the intercept and time trend in the co-integration vectorand following models were tested in this regard: The first model: without intercept and time trend, The second model: with bounded intercept and without time trend, the third model: unbounded intercept and bounded time trend.

At first, the null hypothesis which was the absence of co-integration vector in all the models was rejected and so it was proved that there is at least one co-integration vector among variables in all the models. The summary of results of Trace and maximum eigenvalues tests, regarding the number of co-integration vectors are presented in Table 3 .

Table3. The results of the effectiveness andmaximum eigenvalues tests regarding the number of co-integration vectors

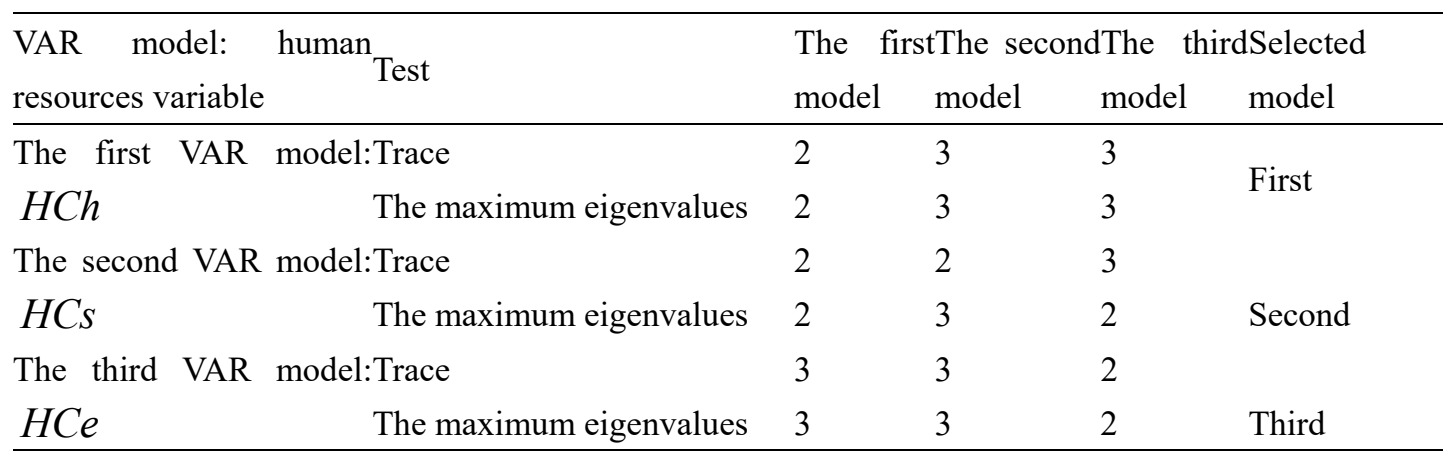

Source: research findings

Co-integration and normalized vectors which show the long-term relationship between the variables are shown in Table 4.

Table4. The results of Johansen co-integration test (numbers in parentheses represent the statistics)

\begin{tabular}{|c|c|c|c|c|c|c|}
\hline \multicolumn{2}{|c|}{ VAR model: human resources variableVector } & \multirow{2}{*}{$\frac{\mathrm{C}}{\mathrm{n}}$} & \multirow[t]{2}{*}{$\mathrm{T}$} & \multicolumn{3}{|c|}{$\log (\mathrm{GDP}) \log (\mathrm{HCi}) \log (\mathrm{K})$} \\
\hline \multirow{4}{*}{$\begin{array}{l}\text { The first VAR model: } \\
H C h\end{array}$} & Co-integration & & & \multirow[t]{2}{*}{-24.43} & \multirow[t]{2}{*}{9.56} & \multirow[t]{2}{*}{14.32} \\
\hline & & - & - & & & \\
\hline & Normalized & - & - & -1 & 0.22 & 0.46 \\
\hline & & & & & (24.33) & (44.56) \\
\hline \multirow{3}{*}{$\begin{array}{l}\text { The second VAR model: } \\
H C s\end{array}$} & \multicolumn{4}{|c|}{ Co-integration 276.480 .7520 .43} & -9.28 & 63.48 \\
\hline & \multirow[t]{2}{*}{ Normalized } & \multirow{2}{*}{\multicolumn{3}{|c|}{$-19.65-0.69-1$}} & 0.18 & 8.5 \\
\hline & & & & & $(6.27)$ & (25.48) \\
\hline \multirow{3}{*}{$\begin{array}{l}\text { The third VAR model: } \\
H C e\end{array}$} & \multicolumn{3}{|c|}{ Co-integration 287.47- } & -26.39 & 5.24 & 42.61 \\
\hline & \multirow[t]{2}{*}{ Normalized } & \multirow{2}{*}{\multicolumn{2}{|c|}{$-4.27-$}} & -1 & 0.073 & 3.19 \\
\hline & & & & & $(\mathbf{5 . 8 3})$ & $(33.22)$ \\
\hline
\end{tabular}

Source: Research findings

According to the results presented in Table 4, the estimated coefficients of the variables, in all models are statistically significant at the 5\% level of confidence;therefore, there is a long run equilibrium relationship between the variables. In all models the elasticity of GDP is positive compared to the physical capital stock,therefore the physical capital stock has a positive and significant impact on GDP. Also in response to the first research question, i can say that in the estimated modelsdevelopment ofhuman capital indicatorshas had a positive impact on economic growth. According to the results of Table 4 and in response to the second research 
question, i must say that in long-term relationships, the largest human capital index coefficients respectively belong to employees with higher education, secondary and elementary education. So, in the long run, when the proportion of employees with higher education increases for one percent, then the economic growth will increase by 0.22 percent. Also, in the long run, with one percent increase in the proportion of employees with secondary and elementary education, the economic growth will increase by 0.18 and 0.073 percent, respectively. These results indicate that in Iran the economic growth is more sensitive to higher education compared to other levels of education.

\subsection{Discussion and Conclusion}

In this study, i used annual data of variables including the GDP, net capital stock at constant prices of 2004 and percentage of employees with their educational status and also i used vector auto regression method to analyze the long-term relationship between each of the educational levels and it was clarified that higher education, secondary and elementary levels have had the greatest impact on GDP growth, respectively. Although, needs to be noted that there is not much difference between coefficients of higher education (0.22) and secondary education (0.18), these results are Almost consistent with the findings of Pereira \& Aubyn(2009), Barro (2002), Sterlacchini (2008), Kreishan (2011) and Shahbazi et al (2012) which indicate that the authorities must pay more attention to higher education in the distribution of educational funds among different educational levels. With the development of our country in different advanced technologies, the effectiveness of higher education employees has increased and on the other hand, the effectiveness of elementary and secondary education has been reduced relatively. It is predicted that this trend continues with more development of the country. The experience of those countries which have emphasized on basic education in the early stages of their economic development and have achieved greater development proves this point, as well.

However, In paying attention to higher education we shouldn't forget that low levels of education (elementary and secondary) are necessary for admission and publication of existing technologies and they are the prerequisites for higher levels of education and must be qualitatively developed. One of the major limitations of this study was absence of annual data on educational level of employeesin a long term period and alsoinformation about the quality and the type of education.

\section{References}

Abdoli, G., \& Varahrami, V. (2009). A survey of impacts of highereducation in economic growth: An empirical study of Iran. QuarterlyJournal of Research and Planning in Higher Education, 15(2), 105-125(in Persian).

Akguç, M. (2011). The effects of different stages of education onincome across countries. Working paper, Toulouse School ofEconomics (TSE).

Almasi, M., \& Gharehbaba, S. (2009). Study on the relationshipbetween investment on human resource and physical capital with economic growth in Iran (1971-2005). Quarterly Journal of Researchand Planning in Higher Education, 15(3), 157-184 (in Persian).

Ansari, A. (1992). Nvestigating the role of education in labor productivity in the economy of Iran, Faculty of Economics, AllamehTabatabai University, MA thesis. (in Persian)

Barro, R. J.. \& Lee, J. W. (2000). International Data on Educational Attainment: Updates and Implications; NBER Working Paper, 791.

Heidari, H., Dabbag, R., \& Sanginabadi, B. (2011). The effect of higher education on economic growth in Iran: An application of bounds test approach. Quarterly Journal of Research and Planning in HigherEducation, 17(1), 115-136 (in Persian).

Islam, M. R. (2010). Human capital composition, proximity to technology frontier and productivity growth. Monash Economics Working Papers, 23-10. Monash University, Department of Economics.

Kreishan, F. M. (2011). Education and economic growth in Jordan: Causality test. International Journal of Economic Perspectives, 5(1). 1-21

Lin, T. C. (2004). The Role of Higher Education in Economic Development: An Empirical Study of Taiwan Case"; Journal of Asian Economics, 15(2), 355-371.

McMahon, W. W. (2009). Higher Learning, Greater Good: The private and social benefits of higher education.Baltimore: The Johns Hopkins University press.

Naderi, A. (2004). Economics of Education, Tehran: Yastaroon Publication. (in Persian)

Naderi, A. (2014a). Advanced discussions in Economics of Education (external efficiency and effectiveness), 
Publications of University of Tehran, 2014, 261. (in Persian)

Naderi, A. (2014b), Education and Economic Growth in Iran: a fundamental evaluation of theoretical and methodological issues and challenges, Journal of Planning and Budget, No. 3, fall, 129-93. (in Persian)

Papageorgiou, C. (2003). Distinguishing between the effects of primary and post-primary education on economic growth. Review of Development Economics, 7(4), 622-635.

Pereira, J., \& Aubyn, M. S. (2009). What level of education matters most for growth? Evidence from Portugal. Economics of Education Review, 28(1), 67-73.

Petrakis, P. E., \& Stamatakis, D. (2002). Growth and educational levels: A comparative analysis. Economics of Education Review, 21(5), 513-521.

Philippe S. J. (2006). Natural Resource Abundance and Human Capital Accumulation, World Development, Elsevier, 34(6), 1060-1083

Raymo, J. (1995). Are investments in higher education productive: Evidence from Japanese time series data.Osaka City University Economic Review, 30(1), 53-65.

Salehi, M. J. (2002). The Effect of Human Capital on Economic Growth in Iran. Journal of Research and Planning in Higher Education, 8(1-2), 43-73(in Persian).

Self, S., \& Grabowski, R. (2004). Does education at all levels cause growth India: A case study. Economics of Education Review, 23(1), 47-55.

Shahbazi, K.,Hasani, M. (2012).The impact of different levels of education on Iran's economic growth, Journal of Research and Planning in Higher Education, Issue 66, 1-24. (in Persian)

Simoes, M. C. N. (2011). Education composition and growth: A pooled mean group analysis of OECD countries. Panoeconomicus, 58(4), 455-471.

Solow, Robert M. (1956). A Contribution to the Theory of Economic Growth. Quarterly Journal of Economics, $70(1), 65-94$

Sterlacchini, A. (2008). R\&D, Higher Education and Regional Growth: Uneven Linkages among European Regions, Research Policy, 37(6-7), 1096-1107.

Zaranezhad, M. \& Ansari, E. (2009). Higher education and gross domestic product (GDP) in Iran. Iranian Economic Research, 10(37), 61-79 (in Persian).

\section{Copyrights}

Copyright for this article is retained by the author(s), with first publication rights granted to the journal.

This is an open-access article distributed under the terms and conditions of the Creative Commons Attribution license (http://creativecommons.org/licenses/by/3.0/). 